\title{
KINERJA PENYULUH PERTANIAN LAPANGAN DAN PRODUKTIVITAS USAHATANI PADI SAWAH (KASUS PETANI PADI DI KECAMATAN KALIREJO KABUPATEN LAMPUNG TENGAH)
}

\author{
(Performance of Agricultural Extension Agents and the Productivity of Paddy Rice - Case of Rice Farmers \\ in Kalirejo Sub-District, Central Lampung District)
}

Tri Pujiana, Tubagus Hasanuddin, Sumaryo Gs

Jurusan Agribisnis, Fakultas Pertanian, Universitas Lampung, Jl. Prof. Dr. Soemantri Brojonegoro No.1 Bandar Lampung 35141, Telp. 085768400607, e-mail: tripujiana.unila@gmail.com

\begin{abstract}
The objectives of this study were to analyze the performance of agricultural extension agents (PPL), factors related to PPL performance, the relationship between PPL performance and productivity of the rice and the relationship between the productivity and paddy rice income in Kalirejo. This study uses a survey method on rice farming in Kalirejo, Central Lampung. The data was collected in October 2017 by interviewing 53 respondents consist of 8 PPLs and 45 rice farmer who were drawn by purposive sampling method. The data was analyzed by qualitative-descriptive analysis, tabulation and Rank Spearman correlation. The study showed that the performance of PPL in BPP Kalirejo was considered high. The competence, work environment, motivation and leadership PPL are related to the performance of PPL. The performance of $P P L$ was related to the productivity of rice. However the productivity was not related to the income of rice farming. Although, the productivity of the rice was increasing, income of the rice farmer was considered low due to low price of rice.
\end{abstract}

Key words: income, performance, productivity

\section{PENDAHULUAN}

Pertanian sebagai salah satu sumber pendapatan penduduk Indonesia memberikan sumbangan pada perekonomian negara. Pembangunan di sektor ini diupayakan untuk memenuhi kebutuhan pangan dalam negeri, meningkatkan pendapatan penduduk, memperluas lapangan kerja dan kesempatan berusaha, serta mendukung pembangunan nasional. Di Indonesia terdapat beberapa sentra produksi padi, salah satunya yaitu Provinsi Lampung.

Produksi padi di Provinsi Lampung mengalami peningkatan antara 4-9 persen pada tahun 2014 sampai tahun 2016, dengan rata-rata luas panen padi sebesar 665.222 ha dan rata-rata produksi padi sebesar 3.391.386,90 ton. Pemerintah Provinsi Lampung ikut mengupayakan peningkatan produktivitas padi dengan berbagai cara, salah satunya dengan menyediakan tenaga penyuluh pertanian. Menurut Peraturan Menteri Pertanian Nomor 01 tahun 2008, percepatan pembangunan pertanian ditempuh melalui revitalisasi penyuluhan pertanian dengan kebijakan satu desa satu penyuluh guna meningkatkan pendapatan dan kesejahteraan petani.
Menurut Slamet (2003), program penyuluhan yang efektif dan efisien dapat dikembangkan oleh tenaga profesional di bidang pertanian. Penyelenggaraan penyuluhan pertanian di Indonesia diarahkan untuk menciptakan kemandirian petani agar mampu berusahatani dengan baik dan dapat memiliki kehidupan yang layak berdasarkan sumberdaya yang ada di sekitar petani. Hal ini sangat membutuhkan kinerja PPL yang terintegrasi pada pelaksanaan tugas pokok dan fungsi PPL.

Salah satu kabupaten di Provinsi Lampung yang memiliki lahan pertanian yang potensial adalah Kabupaten Lampung Tengah. Hal tersebut dapat dilihat dari besarnya luas panen dan produksi padi yang ada di kabupaten tersebut. Berdasarkan data BPS tahun 2017, Kabupaten Lampung Tengah menempati urutan pertama produksi padi di Provinsi Lampung. Kabupaten Lampung Tengah memiliki luas panen padi sebesar 157.873 ha atau 21,42 persen dari total luas panen di Provinsi Lampung dengan produksi mencapai 805.261 ton atau 21,01 persen dari total produksi di Provinsi Lampung.

Lampung Tengah merupakan daerah penghasil beras tertinggi di Provinsi Lampung yang terbagi menjadi 28 kecamatan. Salah satu kecamatan yang 
produktivitas padinya meningkat setiap tahunnya adalah Kecamatan Kalirejo. Produktivitas tanaman padi di kecamatan tersebut pada tahun 2014 mencapai 5,34 ton/ha meningkat menjadi 5,37 ton/ha tahun 2015 dan meningkat lagi di tahun 2016 menjadi 5,42 ton/ha (BPS 2017).

Keberhasilan petani dalam meningkatkan produksi padi salah satunya disebabkan adanya campur tangan dari penyuluh. Salah satu indikator adanya campur tangan tersebut adalah kinerja penyuluh itu sendiri, apabila kinerja penyuluh itu baik maka petani akan berkembang dan kesejahteraannya pun akan meningkat yang ditunjukkan dari peningkatan produktivitas padinya. Oleh sebab itu, penelitian ini bertujuan untuk menganalisis kinerja PPL di BPP Kalirejo, mengetahui faktor-faktor yang berhubungan dengan kinerja PPL, mengetahui hubungan antara kinerja PPL dengan produktivitas padi, dan mengetahui hubungan antara produktivitas padi dengan pendapatan usahatani padi di Kecamatan Kalirejo Kabupaten Lampung Tengah.

\section{METODE PENELITIAN}

Penelitian ini menggunakan metode survei pada usahatani padi di Kecamatan Kalirejo Kabupaten Lampung Tengah dengan pertimbangan kecamatan tersebut merupakan salah satu sentra produksi padi di Lampung Tengah dengan produktivitas padinya yang meningkat setiap tahun. Waktu pengambilan data dilakukan pada Bulan Oktober 2017. Jenis data yang diambil yaitu data primer dan data sekunde. Data primer diperoleh dari wawancara dan data sekunder yang diperoleh dari instansi pemerintah serta literatur terkait.

Populasi pada penelitian ini adalah PPL dan petani binaannya di BPP Kalirejo. Penentuan sampel PPL dan petani binaan dilakukan dengan metode purposive sampling. PPL di BPP Kalirejo berjumlah delapan orang dan seluruhnya dijadikan sebagai sampel penelitian. Setiap wilayah binaan PPL diambil dua desa, kecuali wilayah binaan Bapak M. Su'ud hanya diambil satu desa untuk sampel karena hanya membina satu desa saja. Setiap desa diambil satu kelompok tani dan dipilih tiga orang yang terdiri dari satu pengurus dan dua anggota, sehingga diperoleh 15 kelompok tani dengan 45 petani binaan di BPP Kalirejo. Total sampel pada penelitian ini berjumlah 53 orang.

Kinerja PPL dianalisis menggunakan metode tabulasi dan deskriptif kualitatif. Metode ini seperti yang dilakukan oleh Anggunanda (2016) yang berjudul efektivitas kepemimpinan ketua kelompok tani dalam difusi inovasi pengelolaan tanaman terpadu padi di Kabupaten Lampung Selatan. Pengukuran kinerja PPL menggunakan skor yang terdiri dari satu sampai tiga. Selanjutnya skor diklasifikasikan ke dalam tiga kategori, yaitu kategori rendah, sedang, dan tinggi.

Faktor-faktor yang berhubungan dengan kinerja PPL dianalisis menggunakan korelasi Rank Spearman (Siegel 1997) dengan menggunakan program SPSS 16 (Statistical Package for Social Science). Fator-faktor yang diduga berhubungan dengan kinerja PPL di Kecamatan Kalirejo antara lain kompetensi, lingkungan kerja, motivasi, dan kepemimpinan PPL. Korelasi Rank Spearman juga digunakan untuk mencari hubungan antara kinerja PPL dengan produktivitas padi, serta hubungan antara produktivitas padi dengan pendapatan usahatani padi di Kecamatan Kalirejo Kabupaten Lampung. Data yang diperoleh adalah data ordinal sehingga perlu ditransformasi menjadi data interval dengan menggunakan program MSI (Method of Succesiv Interval).

Kaidah pengambilan keputusannya adalah sebagai berikut:

1. Jika nilai Sig $>\alpha$ maka hipotesis ditolak, pada $(\alpha)=0,1$ berarti tidak terdapat hubungan antara kedua variabel yang diuji.

2. Jika nilai Sig $\leq \alpha$ maka hipotesis diterima, pada $(\alpha)=0,1$ berarti terdapat hubungan yang nyata antara kedua variabel yang diuji.

\section{HASIL DAN PEMBAHASAN}

\section{Kinerja Penyuluh Pertanian Lapangan}

Penilaian kinerja penyuluh pertanian berdasarkan Undang-Undang No.16 Tahun 2006 yang berisi tentang sembilan indikator keberhasilan penyuluh pertanian. Kinerja PPL di BPP Kalirejo termasuk dalam klasifikasi tinggi dengan rincian pada tugas pokok menyusun programa penyuluhan pertanian, menyusun rencana kerja tahunan penyuluhan pertanian, menumbuhkembangkan keberdayaan dan kemandirian petani binaan, meningkatkan produktivitas agribisnis komoditas unggulan serta pendapatan petani binaan berada pada klasifikasi tinggi, sedangkan kinerja PPL untuk tugas pokok menyusun data peta wilayah, mendiseminasikan informasi teknologi pertanian, mewujudkan kemitraan dan akses ke lembaga keuangan, informasi dan sarana produksi berada pada klasifikasi sedang. Sebaran nilai modus PPL di BPP Kalirejo dapat dilihat pada Tabel 1 berikut ini. 
Tabel 1. Rekapitulasi indikator kinerja PPL di BPP Kalirejo

\begin{tabular}{|c|c|c|c|}
\hline No & Indikator Kinerja PPL & Modus & Klasifikasi \\
\hline 1. & $\begin{array}{l}\text { Menyusun programa } \\
\text { penyuluhan pertanian }\end{array}$ & 3 & Tinggi \\
\hline 2. & Menyusun RKTP & 3 & Tinggi \\
\hline 3. & $\begin{array}{l}\text { Menyusun peta wilayah } \\
\text { penyuluhan pertanian }\end{array}$ & 2 & Sedang \\
\hline 4. & $\begin{array}{l}\text { Mendiseminasikan } \\
\text { informasi teknologi } \\
\text { pertanian }\end{array}$ & 2 & Sedang \\
\hline 5. & $\begin{array}{l}\text { Menumbuhkembangkan } \\
\text { keberdayaan dan } \\
\text { kemandirian }\end{array}$ & 3 & Tinggi \\
\hline 6. & $\begin{array}{l}\text { Mewujudkan kemitraan } \\
\text { yang menguntungkan }\end{array}$ & 2 & Sedang \\
\hline 7. & $\begin{array}{l}\text { Mewujudkan akses ke } \\
\text { lembaga keuangan, } \\
\text { informasi dan saprodi }\end{array}$ & 2 & Sedang \\
\hline 8. & $\begin{array}{l}\text { Meningkatkan produktivitas } \\
\text { agribisnis komoditas } \\
\text { unggulan }\end{array}$ & 3 & Tinggi \\
\hline 9. & $\begin{array}{l}\text { Meningkatkan pendapatan } \\
\text { dan kesejahteraan }\end{array}$ & 3 & Tinggi \\
\hline & Tingkat kinerja PPL & 3 & Tinggi \\
\hline
\end{tabular}

1. Tersusunnya programa penyuluhan pertanian

Programa penyuluhan pertanian adalah rencana tertulis yang disusun secara sistematis oleh PPL untuk memberikan pedoman kepada petani dalam mencapai tujuan penyuluhan. Penyusunan ini dilakukan dalam beberapa tahap, yaitu perumusan keadaan, penetapan tujuan, penetapan masalah, penetapan rencana kegiatan, penetapan rencana monitoring, evaluasi hingga revisi.

Kinerja PPL di BPP Kalirejo dalam menyusun programa penyuluhan pertanian berdasarkan jawaban PPL berada pada modus tiga dan diklasifikasikan menjadi tinggi, namun petani binaan di BPP Kalirejo menilai kinerja PPL termasuk dalam klasifikasi sedang. Perbedaan penilaian ini dikarenakan tidak semua anggota kelompok tani ikut menyusun programa. PPL hanya berkoordinasi dengan pengurus kelompok tani seperti ketua atau sekertaris.

\section{Tersusunnya recana kerja tahunan penyuluh pertanian}

Rencana Kerja Tahunan Penyuluh (RKTP) yaitu kegiatan yang disusun oleh PPL berdasarkan programa penyuluhan yang dilengkapi dengan halhal yang dianggap perlu dalam berinteraksi dengan pelaku utama dan pelaku usaha. Rencana Kerja Tahunan Penyuluh Pertanian merupakan landasan pelaksanaan kegiatan penyuluhan pada tahun sedang berjalan atau tahun yang bersangkutan, juga dapat dipakai sebagai alat kendali pelaksanaan evaluasi pencapaian kinerja PPL. Rencana Kerja Tahunan Penyuluh disusun oleh setiap PPL pada akhir tahun dan dilaksanakan di tahun berikutnya.

Kinerja PPL di BPP Kalirejo dalam menyusun RKTP berada pada modus tiga dan diklasifikasikan menjadi tinggi. Lima orang PPL di BPP Kalirejo rutin melaksanakan pembaharuan setiap tahun, sedangkan tiga lainnya tidak rutin melaksanakan pembaharuan setiap tahun. Penyuluh menggunakan program desa, kebutuhan petani, potensi desa dan RKTP tahun lalu sebagai acuan dalam penyusunan RKTP. Persentase terlaksananya RKTP berada pada klasifikasi sedang, tujuh orang menjawab antara 50-75 persen RKTP yang terlaksana. Hal ini menunjukkan bahwa PPL telah menyusun RKTP dengan cukup baik.

3. Tersusunnya data peta wilayah binaan untuk pengembangan teknologi spesifik lokasi

Data peta wilayah untuk pengembangan teknologi spesifik lokasi adalah data peta wilayah binaan penyuluh yang disusun untuk mengembangkan teknologi baru yang disesuaikan dengan potensi wilayah. Peta wilayah dibuat untuk mengetahui apa saja potensi di wilayah tersebutAdanya peta wilayah maka teknologi akan tersebar merata ke seluruh petani binaan PPL.

Kinerja PPL di BPP Kalirejo dalam menyusun data peta wilayah memiliki modus dua dan diklasifikasikan menjadi sedang. Tiga orang PPL di BPP rutin melakukan pembaharuan data peta wilayah setiap tahun, sedangkan lima orang lainnya tidak rutin melaksanakan pembaharuan setiap tahunnya. Unsur yang terdapat dalam peta wilayah antara lain gambar peta wilayah, batas desa, keterangan jalan dan pemukiman penduduk. PPL menggunakan PRA dan data-data lama yang sudah ada sebagai acuan penyusunan data peta wilayah. Hal tersebut menunjukkan bahwa PPL di BPP Kalirejo telah menyusun data peta wilayah dengan cukup baik.

\section{Terdiseminasinya informasi teknologi pertanian secara merata}

Penyuluh memiliki kewajiban untuk menyebarkan informasi teknologi padi sesuai dengan kebutuhan petani. Penyuluh mendapatkan informasi teknologi pertanian dari media ekektronik, media cetak, lembaga penelitian, maupun instansi terkait. Informasi yang didapatkan kemudian disebar ke petani menggunakan media ekektronik dan cetak, 
demonstasi, dan alat peraga/sampel. Biasanya PPL menyebarkan informasi langsung ke petani atau melalui perwakilan kelompok tani, perangkat desa, dan dari satu petani ke petani lainnya.

Kinerja PPL dalam mendiseminasikan informasi teknologi pertanian memiliki modus dua dan diklasifikasikan menjadi sedang. Empat orang PPL di BPP Kalirejo sudah menyebarkan informasi ke lebih dari 75 persen dari jumlah petani, sedangkan empat orang lainnya menyebarkan informasi ke 50-70 persen dari jumlah petani. Hal tersebut menunjukkan bahwa PPL telah mendiseminasikan informasi teknologi pertanian dengan cukup baik. Hasil penelitian ini sejalan dengan hasil penelitian Aria, Hasanuddin dan Prayitno (2016) yang menyebutkan bahwa peranan PPL sudah baik dalam mendiseminasikan informasi Pengembangan Usaha Agribisnis Pedesaan (PUAP).

5. Tumbuh kembangnya keberdayaan dan kemandirian pelaku utama dan pelaku usaha

Keberdayaan dan kemandirian petani tidak terlepas dari peranan seorang penyuluh dalam membantu petani menjadi lebih mandiri. Kinerja PPL dalam menumbuhkembangkan keberdayaan petani dan kemandiriannya di Kecamatan Kalirejo termasuk dalam klasifikasi tinggi. Pemberdayaan petani yang dilakukan penyuluh seperti pembentukan kelompok ekonomi produktif dan mendorong petani menyelesaikan masalah terkait dengan usahataninya. Kelompok tani yang dibina oleh BPP Kalirejo sudah memiliki nomor regisrasi, struktur organisasi, mampu melaksanakan tugas dan fungsi serta adanya aktivitas penyuluh dan anggota kelompok tani.

6. Terwujudnya kemitraan petani dan pelaku usaha yang menguntungkan

Penyuluh berkewajiban memfasilitasi pertemuan antara petani dengan pelaku usaha guna menjalin kemitraan yang saling menguntungkan sehingga usahatani dapat terus berkembang. Modus PPL dalam mewujudkan kemitraan pelaku utama dan pelaku usaha berada pada skor dua yang termasuk dalam klasifikasi sedang.

Hasil penelitian menunjukkan bahwa sudah terjalin kemitraan antara petani dengan lembaga penyedia sarana produksi. Pihak distributor merupakan lembaga yang ditunjuk oleh pemerintah atau perusahaan yang bekerja sama dengan pemerintah untuk mendistribusikan bantuan sarana produksi kepada kelompok tani. Penyuluh dalam hal ini hanya membantu menghubungkan kedua belah pihak dengan membuatkan Rencana Definitif Kebutuhan Kelompok (RDKK) bersama kelompok tani. Rencana definitif kebutuhan kelompok ini yang menjadi prasyarat saat mengambil atau membeli sarana produksi ke distributor.

Sebagian besar petani menilai bahwa upaya yang telah dilakukan penyuluh kurang optimal dalam mewujudkan kemitraan petani dengan pelaku usaha.Hal ini terbukti tidak adanya realisasi kerjasama oleh mitra usaha yang dijembatani oleh penyuluh selain kerjasama penyedia sarana produksi yang ada. Petani mencari modal untuk usahataninya sendiri dan memasarkan hasil-hasil panennya tanpa bantuan penyuluh.

7. Terwujudnya akses pelaku utama dan pelaku usaha ke lembaga keuangan, informasi dan sarana produksi

Penyuluh berkewajiban memfasilitasi petani dalam memperoleh informasi permodalan dan sarana produksi dengan cara menjembatani akses ke lembaga keuangan dan penyedia sarana produksi. Kinerja PPL dalam mewujudkan akses ke lembaga keuangan, informasi dan sarana produksi menurut PPL yaitu termasuk dalam modus dua pada klasifikasi sedang dan menurut petani termasuk dalam modus satu pada klasifikasi rendah.

Berdasarkan hasil penelitian, akses yang sudah terbentuk yaitu dengan lembaga sarana produksi dengan informasi yang disampaikan adalah harga, ketersediaan barang, jenis komoditas dan cara penggunaannya. Penyuluh belum mewujudkan akses antara petani dengan lembaga keuangan dan lembaga informasi.Hal ini disebabkan belum tersedianya lembaga keuangan dan penyedia informasi di masing-masing wilayah binaan PPL.

8. Terwujudnya peningkatan produktivitas agribisnis komoditas unggulan di wilayahnya

Penyuluh berkewajiban membantu petani dalam meningkatkan produktivitas agribisnis komoditi unggulan di wilayah kerja.kinerja PPL dalam mewujudkan peningkatan produktivitas agribisnis komoditas unggulan berada pada modus tiga dan termasuk dalam klasifikasi tinggi. Secara umum komoditas unggulan di Kecamatan Kalirejo adalah padi. Kinerja penyuluh dalam meningkatkan produktivitas agribisnis komoditas unggulan sangat diharapkan petani, agar terwujudnya hal tersebut penyuluh harus lebih aktif lagi. 
Penyuluh akan memetakan komoditas unggulan berdasarkan potensi wilayah, luas lahan, produksi dan produktivitas padi, serta jumlah petani yang mengusahakannya. Penyuluh merekomendasikan teknologi baru kepada petani dan memberikan penyuluhan untuk mewujudkan peningkatan produktivitas padi. Produktivitas padi dalam hal ini dihtung dari rata-rata produktivitas dua musim tanam dalam satu tahun. Produktivitas padi di wilayah kerja BPP Kalirejo berada dalam klasifikasi sedang yaitu sebesar 4,78 ton/ha. Produktivitas padi petani binaan BPP Kalirejo ratarata meningkat sebesar 9,19 persen dari produktivitas tahun sebelumnya.

\section{Meningkatkan pendapatan pelaku utama}

Penyuluh berkewajiban membantu petani dalam meningkatkan produksi padinya yang akan berdampak pada peningkatan pendapatan usahatani petani binaan. Kinerja PPL dalam meningkatkan pendapatan petani binannya berada pada modus tiga dan termasuk dalam klasifikasi tinggi. Peningkatan pendapatan petani tersebut tidak terlepas dari kegiatan penyuluhan yang menambah dan meningkatkan pengetahuan petani dalam melakukan usahataninya serta mengubah perilaku petani dalam membudidayakan padi.

Pendapatan yang diukur adalah pendapatan petani dari hasil penjualan padi dalam bentuk gabah kering panen (GKP) setelah dikurangi biaya produksi usahatani. Pendapatan petani di Kecamatan Kalirejo Kabupaten Lampung Tengah rata-rata sebesar Rp17.752.692,08 per tahun. Selain itu, 80 persen responden pada penelitian ini memiliki pendapatan antara Rp5.124.317,46Rp24.531.075,09 dan termasuk dalam klasifikasi rendah. Rendahnya pendapatan petani tersebut disebabkan oleh besar biaya usahatani yang harus dikeluarkan, rendahnya harga jual padi, jumlah produksi padi yang masih rendah, dan kualitas padi itu sendiri.

Menurut responden, setelah diberikan penyuluhan pendapatan usahatani padi petani binaannya ratarata meningkat sebesar Rp4.066.883,56 dari tahun sebelumnya. Meningkatnya pendapatan usahatani tersebut dikarenakan adanya peningkatan pada produksi usahataninya. Penyuluh memberikan arahan dan pendampingan kepada petani untuk meningkatkan wawasan petani dan memperbaiki sistem usahataninya. Peningkatan pendapatan usahatani padi petani binaan BPP Kecamatan Kalirejo dapat dilihat pada Tabel 2 berikut ini.
Tabel 2. Pendapatan usahatani padi di wilayah kerja BPP Kalirejo

\begin{tabular}{lrr}
\hline \multicolumn{1}{c}{ Aspek } & \multicolumn{1}{c}{ Tahun 2016} & \multicolumn{1}{c}{ Tahun 2017} \\
\hline Harga (Rp/kg) & $4.300,00$ & $4.588,00$ \\
Produksi (kg) & 5.200 & 5.760 \\
Penerimaan (Rp) & $22.361 .605,33$ & $26.428 .488,89$ \\
Biaya Produksi (Rp) & $8.675 .797,00$ & $8.675 .797,00$ \\
Pendapatan (Rp) & $13.685 .808,52$ & $17.752 .692,08$ \\
Persentase (\%) & - & 31,36 \\
\hline
\end{tabular}

Berdasarkan Tabel 2, dapat dilihat bahwa selisih pendapatan yang diterima petani padi dari tahun sebelumnya sebesar Rp4.066.883,56. Pendapatan yang diperoleh petani meningkat sebesar 31,36 persen dengan diberikannya penyuluhan dan pendampingan kepada petani. Hal ini menunjukkan adanya pengaruh positif keberadaan PPL terhadap pendapatan petani. Hasil penelitian ini sejalan dengan penelitian Prasetia, Hasanuddin, dan Viantimala (2015) yang menyebutkan bahwa pendapatan petani meningkat setelah bergabung dengan kelompok tani. Kelompok tani berperan sebagai wadah yang mampu menumbuhkan kemandirian dan meningkatkan kemampuan anggotanya dalam melaksanakan usahatani.

Keberadaan PPL yang membawa dampak positif bagi petani juga dilihat dari analisis imbangan penerimaan dan biaya usahatani. Hasil analisis imbangan penerimaan dan biaya (R/Cratio analysis) menunjukkan bahwa usahatani padi ini memiliki penerimaan usahatani padi lebih besar dibandingkan dengan biaya usahatani padi. Nilai $\mathrm{R} / \mathrm{C}$ atas biaya total sebesar 2,95, artinya setiap $\mathrm{Rp}$ 1 biaya total yang dikeluarkan dapat menghasilkan penerimaan sebesar Rp 2,95. Berdasarkan nilai $\mathrm{R} / \mathrm{C}$ atas biaya total yang didapat, dapat disimpulkan bahwa usahatani padi sawah petani binaan BPP Kalirejo menguntungkan sebab nilai $\mathrm{R} / \mathrm{C}$ lebih dari satu $(\mathrm{R} / \mathrm{C}>1)$.

\section{Faktor-faktor yang Berhubungan dengan Kinerja PPL}

Keberhasilan pelaksanaan penyuluhan pertanian tidak lepas dari ketersediaan PPL.Secara kuantitas, jumlah PPL tidak sebanding dengan jumlah wilayah binaan yang ada, setiap PPL menangani wilayah binaan sebanyak 1-3 desa. Oleh karena itu penting untuk diteliti beberapa faktor yang diperkirakan berhubungan dengan kinerja PPL. Faktor-faktor tersebut terdiri dari kompetensi, faasilitas kerja, lingkungan sosial, motivasi, dan kepemimpinan PPL. Hasil analisis hubungan antara faktor-faktor yang berhubungan dengan kinerja PPL) dapat dilihat pada Tabel 3. 
Tabel 3. Hasil analisis hubungan antara variabel $\mathrm{X}$ dengan variabel $\mathrm{Y}$

\begin{tabular}{cccccc}
\hline No & Variabel X & $\mathrm{r}_{\mathrm{s}}$ & Sig. & $\alpha$ & Keputusan \\
\hline 1. & $\mathrm{X}_{1}$ & 0,863 & 0,006 & 0,10 & Terima $\mathrm{H}_{1}$ \\
2. & $\mathrm{X}_{2}$ & 0,082 & 0,847 & 0,10 & Tolak $\mathrm{H}_{1}$ \\
3. & $\mathrm{X}_{3}$ & 0,795 & 0,018 & 0,10 & Terima $\mathrm{H}_{1}$ \\
4. & $\mathrm{X}_{4}$ & 0,737 & 0,037 & 0,10 & Terima $\mathrm{H}_{1}$ \\
5. & $\mathrm{X}_{5}$ & 0,687 & 0,060 & 0,10 & Terima $\mathrm{H}_{1}$ \\
\hline Keterangan: & & & \\
$\mathrm{X}$ & : Faktor-faktor yang berhubungan dengan kinerja PPL \\
$\mathrm{X}_{1}$ & : Kompetensi PPL \\
$\mathrm{X}_{2}$ & : Fasilitas kerja PPL \\
$\mathrm{X}_{3}$ & : Lingkungan sosial PPL \\
$\mathrm{X}_{4}$ & : Motivasi PPL & & \\
$\mathrm{X}_{5}$ & Kepemimpinan PPL & & & \\
$\mathrm{Y}$ & Kinerja PPL & &
\end{tabular}

\section{Kompetensi PPL}

Berdasarkan hasil pengujian hipotesis antara vairabel kompetensi PPL $\left(\mathrm{X}_{1}\right)$ dengan kinerja PPL (Y), diperoleh nilai koefisien korelasi sebesar 0,863 dengan tingkat signifikansi sebesar 0,006. Hal tersebut menunjukkan bahwa kompetensi berhubungan nyata dengan kinerja PPL di Kecamatan Kalirejo. Tabel 3 menunjukkan bahwa nilai korelasi yang diperoleh adalah 0,863 yang berarti kedua variabel memiliki tingkat hubungan yang sangat kuat (Sugiyono, 2013), dan memiliki interpretasi bahwa kinerja PPL ditentukan oleh kompetensi sebesar 86,3 persen, artinya kompetensi akan meningkatkan kinerja PPL di kecamatan tersebut.

Kompetensi PPL diukur dari pengetahuan PPL, keikutsertaan dalam merancang kegiatan, frekuensi pengumpulan data kelompok tani, pemahaman terkait tuntutan organisasi, dan cara penyampaian materi penyuluhan. Pengetahuan PPL dilihat dari kemampuan memahami prinsip, metode, asas penyuluhan. Sebagian besar PPL menjawab lebih dari empat alternatif jawaban terkait prinsip, metode dan asas penyuluhan tersebut. PPL juga ikut membantu dalam merancang kegiatan penyuluhan, hal ini disebabkan adanya kedekatan penyuluh dengan petani binaannya. PPL juga mampu mengarahkan petani dalam berusahatani.

Frekuensi pengumpulan data kelompok tani sebagian besar dilakukan rutin setiap tahun untuk mengetahui kebutuhan petani dan perkembangan produktivitas usahatani padi. PPL juga sudah memahami tuntutan organisasi terhadap dirinya sehingga setiap PPL mampu menempatkan diri dan melaksanakan tugasnya dengan baik. Hasil penelitian tersebut sejalan dengan hasil penelitian Pramudyo (2010) dan Puspita (2011) yang menyimpulkan bahwa variabel bebas kompetensi memiliki hubungan yang cukup kuat dengan variabel terikat kinerja PPL.

\section{Fasilitas Kerja PPL}

Berdasarkan hasil pengujian hipotesis antara variabel fasilitas kerja PPL $\left(\mathrm{X}_{2}\right)$ dengan kinerja PPL (Y), diperoleh nilai koefisien korelasi sebesar 0,082 dengan tingkat signifikansi sebesar 0,487. Hal tersebut menunjukkan bahwa fasilitas kerja tidak berhubungan dengan kinerja PPL di Kecamatan Kalirejo. Fasilitas kerja PPL adalah sarana dan prasarana yang dimiliki oleh PPL dalam mendukung kegiatan penyuluhan. Fasilitas kerja ini terdiri dari kendaraan (mobil/motor), handphone, biaya operasional, poster, papan tulis dan LCD.

Hasil penelitian ini berlawanan dengan hasil penelitian Pramudyo (2010) diperoleh bahwa terdapat hubungan antara fasilitas kerja terhadap kinerja dosen negeri pada kopertis wilayah $\mathrm{V}$ Yogyakarta. Pemberian fasilitas yang lengkap juga dijadikan salah satu pendorong untuk bekerja. Suatu kantor harus mempunyai berbagai macam kelengkapan fasilitas kerja seperti gedung kantor, komputer, meja, kursi, lemari dan fasilitas pendukung lainnya seperti kendaraan dinas.

\section{Lingkungan Sosial PPL}

Berdasarkan hasil pengujian hipotesis antara variabel lingkungan sosial PPL $\left(\mathrm{X}_{3}\right)$ dengan kinerja PPL (Y), diperoleh nilai koefisien korelasi sebesar 0,795 dengan tingkat signifikansi sebesar 0,018. Hal tersebut menunjukkan bahwa lingkungan sosial berhubungan nyata dengan kinerja PPL di Kecamatan Kalirejo. Berdasarkan analisis diperoleh nilai korelasi 0,795 yang menunjukkan bahwa kedua variabel memiliki tingkat keeratan hubungan yang kuat (Sugiyono, 2013), dan memiliki interpretasi bahwa kinerja PPL ditentukan oleh lingkungan sosial sebesar 79,5 persen, yang artinya lingkungan sosial akan meningkatkan kinerja PPL di Kecamatan Kalirejo.

Lingkungan sosial diwakili oleh indikator dukungan terhadap PPL dan lingkungan organisasi. Dukungan terhadap PPL adalah dukungan yang diberikan dari kelompok masyarakat yang terkait dengan penyuluhan. Mereka adalah keluarga, tokoh masyarakat, dan perangkat desa. Lingkungan organisasi adalah dukungan yang diberikan oleh BPP baik pimpinan atau sesama PPL dalam program penyuluhan. Penelitian ini didukung oleh Puspita (2011) dan Potu (2013) yang menyimpulkan lingkungan kerja memberikan 
pengaruh positif dan signifikan terhadap kinerja. Lingkungan kerja yang nyaman dan menyenangkan akan membentuk budaya kerja yang produktif sehingga PPL selalu termotivasi untuk memberikan performa terbaiknya untuk menyelesaikan tugasnya.

\section{Motivasi PPL}

Berdasarkan hasil pengujian hipotesis antara variabel motivasi PPL $\left(\mathrm{X}_{4}\right)$ dengan kinerja PPL (Y), diperoleh nilai koefisien korelasi sebesar 0,737 dengan tingkat signifikansi sebesar 0,037. Hal tersebut menunjukkan bahwa motivasi PPL berhubungan dengan kinerja PPL di Kecamatan Kalirejo. Berdasarkan Tabel 3 dapat dilihat hasil dari analisis diperoleh nilai korelasi sebesar 0,737 yang menunjukkan bahwa kedua variabel memiliki tingkat keeratan hubungan yang kuat (Sugiyono, 2013), dan memiliki interpretasi bahwa kinerja PPL ditentukan oleh lingkungan kerja sebesar 73,7 persen, artinya motivasi maka akan meningkatkan kinerja PPL di kecamatan tersebut.

Dorongan berprestasi yaitu keinginan untuk mengatasi hambatan agar mencapai hasil kerja terbaik. Hal ini dapat dilihat dari keinginan PPL untuk mencapai prestasi dalam bekerja, menjadi penyuluh yang berhasil serta memberikan yang terbaik bagi organisasi dan masyarakat. Dorongan berkompetensi yaitu keinginan untuk menguasai bidangnya. Hal ini tampak dari keinginan untuk belajar, meningkatkanketerampilan membantu memecahkan masalah petani binaan dan selalu berinovasi dalam menjalankan tugas. Adanya pengaruh motivasi pada kinerja PPL ini sejalan dengan hasil penelitian Pramudyo (2010) dan Potu (2013) yang menyimpulkan bahwa motivasi berhubungan nyata pada kinerja penyuluh.

\section{Kepemimpinan PPL}

Berdasarkan hasil pengujian hipotesis antara variabel kepemimpinan PPL $\left(\mathrm{X}_{5}\right)$ dengan kinerja PPL (Y), diperoleh nilai koefisien korelasi sebesar 0,687 dengan tingkat signifikansi sebesar 0,060. Hal tersebut menunjukkan bahwa kepemimpinan berhubungan dengan kinerja PPL di Kecamatan Kalirejo. Berdasarkan Tabel 3 dapat dilihat nilai korelasi 0,687 yang menunjukkan bahwa kedua variabel memiliki tingkat keeratan hubungan yang kuat (Sugiyono, 2013), dan memiliki interpretasi bahwa kinerja PPL ditentukan oleh lingkungan kerja sebesar 68,7 persen, yang artinya kepemimpinan PPL maka akan meningkatkan kinerja PPL di kecamatan tersebut.
Kualitas PPL tidak ditentukan oleh hasil yang dicapai, tetapi ditentukan oleh kemampuan PPL dalam mencapai hasil tersebut dengan perantara orang lain, yaitu melalui petani binaannya, serta pengaruh yang ditimbulkan oleh PPL terhadap petani. PPL harus menggerakkan petani agar mereka bekerja untuk mencapai hasil yang baik. Penelitian ini didukung oleh Pramudyo (2010) dan Potu (2013) yang diperoleh hasil kepemimpinan positif dan signifikan terhadap kinerja.

\section{Analisis Hubungan antara Kinerja PPL dengan Produktivitas Usahatani Padi}

Berdasarkan hasil pengujian hipotesis antara kinerja PPL dengan produktivitas usahatani padi diperoleh nilai koefisien korelasi sebesar 0,379 dengan tingkat signifikansi sebesar 0,010. Hal tersebut menunjukkan bahwa kinerja PPL berhubungan nyata dengan produktivitas usahatani padi di Kecamatan Kalirejo. Berdasarkan analisis diperoleh nilai korelasi 0,379 yang menunjukkan bahwa kedua variabel memiliki tingkat keeratan hubungan yang sedang (Sugiyono, 2013), dan memiliki interpretasi bahwa produktivitas usahatani padi ditentukan oleh kinerja PPL sebesar 37,9 persen, yang artinya semakin tinggi kinerja PPL maka akan semakin tinggi produktivitasnya.

Produktivitas yang dicapai oleh petani BPP Kalirejo tidak terlepas dari kinerja yang dilakukan PPL secara berulang-ulang untuk melakukan penyuluhan dan pembinaan, terutama dalam hal perbaikan budidaya serta penggunaan teknologi pertanian. Kinerja PPL memberikan kontribusi yang nyata terhadap tingkat produktivitas padi di wilayah kerja BPP Kalirejo. Penyuluh sudah memfasilitasi petani dalam hal membantu setiap kegiatan yang sudah diadakan, dan memberikan keterampilan khusus yang menunjang kenaikan produktivitas padi.

\section{Analisis Hubungan antara Produktivitas dan Pendapatan Usahatani Padi}

Pengujian hipotesis tentang hubungan antara produktivitas dan pendapatan usahatani padi di BPP Kalirejo diuji menggunakan uji korelasi Rank Spearman. Berdasarkan hasil pengujian hipotesis antara variabel produktivitas dengan pendapatan usahatani padi diperoleh nilai koefisien korelasi sebesar 0,136 dengan tingkat signifikansi sebesar 0,374. Hal tersebut menunjukkan bahwa produktivitas usahatani padi tidak berhubungan dengan pendapatan usahatani padi di Kecamatan Kalirejo. 
Berdasarkan hasil penelitian yang diperoleh, ratarata produktivitas padi petani binaan di BPP Kalirejo meningkat, namun pendapatan usahatani petani padi termasuk dalam klasifikasi rendah. Rendahnya pendapatan usahatani padi tersebut dikarenakan harga jual padi di kecamatan tersebut masih rendah. Harga jual padi yang rendah disebabkan oleh kualitas gabah, kondisi cuaca saat panen dan pasca panen, agen produk, dan waktu panen. Hasil tersebut berbanding lurus dengan penelitian yang dilakukan oleh Bakhri dan Sudaryono (2016) yang juga menjelaskan bahwa pendapatan petani tidak berpengaruh signifikan terhadap produktivitas padi di Kecamatan Peterongan dan Kecamatan Megaluh Kabupaten Jombang.

\section{KESIMPULAN}

Berdasarkan hasil penelitian dapat disimpulkan bahwa kinerja PPL di BPP Kalirejo termasuk dalam klasifikasi tinggi dengan rincian menyusun programa penyuluhan pertanian dan RKTP, menumbuhkembangkan keberdayaan kemandirian, meningkatkan produktivitas serta pendapatan berada pada klasifikasi tinggi, sedangkan kinerja PPL untuk menyusun data peta wilayah, mendiseminasikan informasi teknologi pertanian, mewujudkan kemitraan dan akses ke lembaga keuangan, informasi dan sarana produksi berada pada klasifikasi sedang. Kompetensi, lingkungan sosial, motivasi dan kepemimpinan berhubungan dengan kinerja PPL, sedangkan fasilitas kerja tidak berhubungan dengan kinerja PPL di BPP Kalirejo. Kinerja PPL juga berhubungan dengan produktivitas padi, namun produktivitas padi tidak berhubungan dengan pendapatan petani padi karena meskipun produktivitas meningkat tetapi pendapatan petani masih rendah. Rendahnya pendapatan petani padi disebabkan oleh harga jual padi di kecamatan tersebut tergolong rendah.

\section{DAFTAR PUSTAKA}

Anggunanda, Hasanuddin T, dan Nurmayasari I. 2016. Efektivitas kepemimpinan ketua kelompok tani dalam difusi inovasi pengelolaan tanaman terpadu padi di Kabupaten Lampung Selatan. JIIA, 4 (4): 423429. http://jurnal.fp.unila.ac.id/index.php/JIA/ article/view/1525/1379. [5 April 2018].

Aria RA, Hasanuddin T, dan Prayitno RT. 2016. Peranan penyuluh pertanian lapangan (PPL) dan keberhasilan program pengembangan usaha agribisnis pedesaan (PUAP) di Kecamatan Sungkai Selatan Kabupaten
Lampung Utara. JIIA, 4 (4): 430-436. http://jurnal.fp.unila.ac.id/index.php/JIA/articl e/view/1526/1380. [19 Desember 2017].

Bakhri FR dan Sudaryono L. 2016. Faktor-faktor yang mempengaruhi produktivitas usahatani antara Kecamatan Peterongan dan Kecamatan Megaluh Kabupaten Jombang. Jurnal Pendidikan Geografi, 3 (3): 416-422. http:// jurnalmahasiswa.unesa.ac.id/index.php/swarabhumi/article/view/17066. [9 Desember 2017].

BPS [Badan Pusat Statistik]. 2017. Lampung dalam Angka 2016. http://lampung.bps.go.id/ [2 April 2018].

Kementrian Hukum dan Hak Asasi Manusia. 2006. Undang-Undang Nomor 16 Tahun 2006 tentang Sistem Penyuluhan Pertanian, Perikanan, dan Kehutanan (UU SP3K). http://perundangan.pertanian.go.id/admin/file/ Permentan-01-08.pdf. [21 Desember 2016].

Kementrian Pertanian. 2018. Peraturan Menteri Pertanian Nomor 01/Permentan/OT.140/1/ 2008 tentang Pedoman Pembinaan Tenaga Harian Lepas (THL) Tenaga Bantu Penyuluh Pertanian. http://perundangan.pertanian.go. id/admin/file/Permentan-01-08.pdf. [27 Maret 2017].

Potu A. 2013. Kepemimpinan, motivasi, dan lingkungan kerja pengaruhnya terhadap kinerja karyawan pada kanwil ditjen kekayaan negara Suluttenggo dan Maluku Utara di Manado. Jurnal EMBA 1 (4): 1208-1218. http://ejournal.unsrat.ac.id/index.php/emba/ article/view/2894. [3 Maret 2017].

Pramudyo A. 2010. Analisis faktor-faktor yang mempengaruhi kinerja dosen negeri pada kopertis wilayah V Yogyakarta. JBTI, 1 (1) 1-11. http://journal.umy.ac.id/index.php/bti/ article/view/2407. [3 Maret 2017].

Prasetia R, Hasanuddin T, dan Viantimala B. 2015. Peranan Kelompok Tani dalam Peningkatan Pendapatan Petani Kopi di Kelurahan Tugusari Kecamatan Sumberjaya Kabupaten Lampung Barat. JIIA, 3 (3): 301-307. http://jurnal.p.unila.ac.id/index.php/JIA/article /view/1055/960. [19 Desember 2017].

Puspita. 2011. Faktor-faktor yang mempengaruhi kinerja penyuluh keluarga berencana dan dampaknya pada kinerja kader KB di tiga kabupaten/kota di Provinsi Jawa Barat. Disertasi. Institut Pertanian Bogor. Bogor. http://repository.ipb.ac.id/handle/123456789/4 6650. [19 Desember 2016].

Siegel S. 1997. Statistik Nonparametrik. PT Gramedia Pustaka Utama. Jakarta. 


\section{JIIA, VOLUME 6 No. 4, NOVEMBER 2018}

Slamet M. 2003. Pemberdayaan Masyarakat Dalam Membentuk Pola Perilaku Manusia Pembangunan. Penyunting: Ida Yustina dan Ajat Sudrajat, 45 - 48. IPB Press. Bogor.
Sugiyono. 2013. Statistika Untuk Penelitian. Alfabeta. Bandung. 